\title{
PENDIDIKAN ISLAM DALAM MENINGKATKAN KUALITAS SUMBER DAYA MANUSIA
}

\author{
Agung \\ Fakultas Ilmu Tarbiyah dan Keguruan \\ Institut Agama Islam Negeri Syekh Nurjati Cirebon \\ email: agungfadil52@gmail.com
}

\begin{abstract}
Abstrak
Konsep sumber daya manusia (human resource) berkembang ketika diketahui dan disadari bahwa manusia itu mengandung berbagai aspek sumber daya bahkan sebagai sumber energi. Manusia tidak hanya berunsur jumlah, seperti terkesan dari pengertian tentang penduduk, tetapi juga mutu, dan mutu ini tidak hanya ditentukan oleh aspek keterampilan atau kekuatan tenaga fisiknya, tetapi juga pendidikannya atau kadar pengetahuannya, pengalaman atau kematangannya, dan sikapnya atau nilai-nilai yang dimilikinya. Kompleksnya persoalan pendidikan di satu sisi dan tuntutan meningkatkan kualitas sumber daya manusia di sisi lain menyebabkan persoalan pendidikan tetap menarik untuk dibahas dengan harapan pembahasan ini mampu memunculkan solusi alternatif dalam mengembangkan kualitas sumber daya manusia lewat jalur pendidikan Islam.
\end{abstract}

Kata Kunci: Pendidikan, Islam, Kualitas dan Sumber Daya Manusia 


\section{A. Pendahuluan}

Realitas Pendidikan Islam saat ini bisa dibilang telah mengalami masa intellectual deadlock. Diantara indikasinya adalah; pertama, minimnya upaya pembaharuan, dan kalau toh ada kalah cepat dengan perubahan sosial, politik dan kemajuan iptek. Kedua, praktek pendidikan Islam sejauh ini masih memelihara warisan yang lama dan tidak banyak melakukan pemikiran kreatif, inovatif dan kritis terhadap isu-isu aktual. Ketiga, model pembelajaran pendidikan Islam terlalu menekankan pada pendekatan intelektualisme-verbalistik dan menegasikan pentingnya interaksi edukatif dan komunikasi humanistik antara guru-murid. Keempat, orientasi pendidikan Islam menitikberatkan pada pembentukan .abd atau hamba Allah dan tidak seimbang dengan pencapaian karakter manusia muslim sebagai khalifah fi al$\operatorname{ardl}^{1}$

Padahal, di sisi lain pendidikan Islam mengemban tugas penting, yakni bagaimana mengembangkan kualitas sumber daya manusia (SDM) agar umat Islam dapat berperan aktif dan tetap survive di era globalisasi. Dalam konteks ini Indonesia sering mendapat kritik, karena dianggap masih tertinggal dalam melakukan pengembangan kualitas manusianya. Padahal dari segi kuantitas Indonesia memiliki sumber daya manusia melimpah yang mayoritas beragama Islam.

Paradigma pembangunan yang berorientasi pada keunggulan komparatif dengan lebih mengandalkan sumber daya alam dan tenaga kerja yang murah, saat ini mulai mengalami pergeseran menuju pembangunan yang lebih menekankan keunggulan kompetitif. Dalam paradigma baru ini, kualitas SDM, penguasaan teknologi tinggi dan peningkatan peran masyarakat memperoleh perhatian. ${ }^{2}$

Keberhasilan pembangunan terutama ditentukan oleh kualitas manusianya, bukan oleh melimpah-ruahnya kekayaan alam. ${ }^{3}$ Manusia merupakan titik sentral yang menjadi subyek dan perekayasa pembangunan serta sebagai obyek yang direkayasa dan menikmati hasil-hasil pembangunan. Sumber daya manusia pun (disamping pada kondisi-kondisi tertentu menjadi beban pembangunan) merupakan modal dasar pembangunan nasional yang memiliki potensi dan daya dorong bagi percepatan proses pelaksanaan pembangunan nasional. Dengan demikian, perilaku pembangunan, seyogyanya senantiasa mencerminkan peningkatan harkat dan martabat kemanusiaan demi peningkatan kualitas peradaban masyarakat bangsa dan negara. Di dalamnya diperlukan ketangguhan kualitas, watak dan moralitas manusia sebagai pelaku utamanya.

Dalam pembangunan, manusia adalah perencana, pelaku, pengendali serta tujuan dari pembangunan itu sendiri. Oleh karena itu pengembangan

\footnotetext{
${ }^{1}$ Abd. Rachman Assegaf, .Membangun Format Pendidikan Islam di Era Globalisasi., dalam Imam Machali dan Musthofa (Ed.), Pendidikan Islam dan Tantangan Globalisasi, (Yogyakarta: Ar-Ruzz Media, 2004), Cet. I, 8-9.

${ }^{2}$ A. Malik Fadjar, Reorientasi Pendidikan Islam (Jakarta: Fajar Dunia, 2009) Cet. I, 156.

${ }^{3}$ Sri Bintang Pamungkas, Dengan Sumber Daya Manusia (SDM) dan IPTEK Mengatasi Kemiskinan, Mencapai Kemandirian (Jakarta: Seminar dan Sarasehan Teknologi, 2003), 20.
} 
kualitas sumber daya manusia merupakan prioritas utama yang harus ditingkatkan, sehingga dengan demikian ia dapat memiliki segala kemampuan yang dibutuhkan dalam pembangunan di segala bidang. Manusia yang berkualitas dapat memanfaatkan segala potensinya dan mampu merebut peluang di masa depan bagi kejayaan bangsa dan negara. Faktor manusia menjadi paling menentukan akan berhasil atau gagalnya bangsa untuk tetap tegak dalam persaingan global karena yang membedakan kemampuan suatu bangsa dengan bangsa lainnya adalah kualitas manusianya.

Upaya pengembangan dan peningkatan kualitas sumber daya manusia dapat dilakukan melalui berbagai jalur, diantaranya melalui pendidikan. Pendidikan ini merupakan jalur peningkatan kualitas sumber daya manusia yang lebih menekankan pada pembentukan kualitas dasar, misalnya keimanan dan ketakwaan, kepribadian, kecerdasan, kedisiplinan, kreativitas dan sebagainya. ${ }^{4}$

Dalam hal pengembangan SDM, pendidikan memiliki nilai strategis danmempunyai peran penting sebagai suatu investasi di masa depan. Karena secarateoretis, pendidikan adalah dasar dari pertumbuhan ekonomi, dasar dariperkembangan sains dan teknologi, mengurangi kemiskinan dan ketimpangan dalampendapatan, dan peningkatan kualitas peradaban manusia pada umumnya. ${ }^{5}$ Nilaistrategis pendidikan yang makro ini, menyimpulkan bahwa pendidikan menyimpankekuatan luar biasa untuk menciptakan keseluruhan aspek lingkungan hidup dandapat memberikan informasi paling berharga mengenai pegangan hidup di masadepan serta membantu anak didik mempersiapkan kebutuhan hidup yang esensialuntuk menghadapi perubahan.

Pendidikan lebih merupakan model untuk pembentukan maupun pewarisan nilai-nilai keagamaan dan tradisi masyarakat. Artinya, misi pendidikan dianggap berhasil ketika anak didik sudah mempunyai sikap positif dalam beragama dan memelihara tradisi masyarakatnya. ${ }^{6}$ Kini, paradigma pendidikan seperti itu harus direkonstruksi agar sumber daya manusia muslim tidak acuh terhadap persoalan yang terkait dengan kepentingan ekonomi, ketenaga-kerjaan, dan persoalan lainnya dengan tetap mempertahankan nilai-nilai etik dan moral Islam.

Titik sentral yang menjadi kunci berhasil atau tidaknya suatu bangsa dalam membangun negaranya tergantung dengan kualitas sumber daya manusianya. Sehingga timbul pertanyaan, sumber daya manusia yang seperti apakah yang dikatakan berkualitas?

\section{B. Pembahasan}

\section{Pengertian Sumber Daya Manusia}

Manusia adalah makhluk yang diciptakan Allah paling sempurna dengan struktur jasmaniah dan rohaniah terbaik di antara makhluk lainnya.

${ }^{4}$ Abdul Latif, Pengembangan Sumber Daya Manusia yang Berkualitas Menghadapi Era Pasar Bebas (Jakarta: DPP HIPPI, 1996), 11.

${ }^{5}$ John Vaizey, Pendidikan di Dunia Modern(Jakarta: Gunung Agung, 1980), 41.

${ }^{6}$ A. Malik Fadjar, Madrasah dan Tantangan Modernitas (Bandung: Mizan, 1999), Cet II, 9. 
Muzayyin Arifin mengatakan bahwa dalam struktur jasmaniah dan rohaniah itu Allah memberikan seperangkat kemampuan dasar yang memiliki kecenderungan berkembang yang menurut aliran psikologi behaviorisme disebut pre potence reflex (kemampuan dasar yang secara otomatis berkembang). ${ }^{7}$

Kemampuan dasar tersebut kemudian dikenal dengan istilah sumber daya manusia atau disingkat dengan SDM. SDM secara konseptual memandang manusia sebagai suatu kesatuan jasmani dan rohani. Oleh sebab itu, kualitas SDM yang dimiliki oleh suatu bangsa dapat dilihat sebagai sinergistik antara kualitas rohani dan jasmani yang dimiliki oleh individu dari warga bangsa yang bersangkutan.

Kualitas jasmani dan rohani tersebut oleh Emil Salim, seperti dikutip oleh Anggan Suhandana, disebut sebagai kualitas fisik dan non fisik. Lebih lanjut, wujud kualitas fisik ditampakkan oleh postur tubuh, kekuatan, daya tahan, kesehatan, dan kesegaran jasmani. Dari sudut pandang ilmu pendidikan, kualitas non fisik manusia mencakup ranah (domain) kognitif, afektif, dan psikomotorik. Kualitas ranah kognitif digambarkan oleh tingkat kecerdasan individu, sedangkan kualitas ranah afektif digambarkan oleh kadar keimanan, budi pekerti, integritas kepribadian, serta ciri-ciri kemandirian lainnya. Sementara itu, kualitas ranah psikomotorik dicerminkan oleh tingkat keterampilan, produktivitas, dan kecakapan mendayagunakan peluang berinovasi. ${ }^{8}$

Sebenarnya tiga kata yang terdapat dalam istilah sumber daya manusia, yaitu: sumber, daya, dan manusia, tak ada satupun yang sulit untuk dipahami. Ketiga kata itu tentu mempunyai arti dan dengan mudah dapat dipahami artinya. Secara sederhana dapat didefinisikan sebagai daya yang bersumber dari manusia. Daya ini dapat pula disebut kemampuan, tenaga, energi, atau kekuatan (power). ${ }^{9}$

Walaupun demikian, istilah sumber daya manusia telah didefinisikan bermacam-macam oleh para pakar pendidikan maupun psikologi. Diantaranya ialah apa yang telah diutarakan oleh Yusuf Suit yang mengatakan bahwa yang dimaksud dengan sumber daya manusia adalah kekuatan daya pikir dan berkarya manusia yang masih tersimpan dalam dirinya yang perlu dibina dan digali serta dikembangkan untuk dimanfaatkan sebaik-baiknya bagi kesejahteraan kehidupan manusia. ${ }^{10}$ Dalam Kamus Besar Bahasa Indonesia, sumber daya manusia diartikan sebagai potensi manusia yang dapat dikembangkan untuk proses produksi. ${ }^{11}$

${ }_{8}^{7}$ Muzayyin Arifin, Ilmu Pendidikan Islam (Jakarta: Bumi Aksara, 2003), 88.

8 Anggan Suhandana, Pendidikan Nasional Sebagai Instrumen Pengembangan SDM(Bandung: Mizan, 2007), Cet. III, 151.

${ }^{9}$ Buchori Zainun, Manajemen Sumber Daya Manusia (Jakarta: Gunung Agung, 2003), Cet. II, 57.

${ }^{10}$ Yusuf Suit, Sikap Mental dalam Manajemen SDM (Jakarta: Ghalia Indonesia, 2006), Cet. I, 35 .

${ }^{11}$ Depdikbud, Kamus Besar Bahasa Indonesia (Jakarta: Balai Pustaka, 1999), Cet. X, 973. 
Sedangkan dalam Kamus Webster, yang dimaksud sumber daya manusia ialah alat atau kekayaan yang tersedia (available means), kemampuan atau bahan untuk menyelesaikan masalah atau persoalan. Definisi dari dua kamus di atas diperkuat oleh pernyataan Deacon dan Malock dalam Gross Crandall dan Knol yang mendefinisikan sumber daya manusia sebagai alat atau bahan yang tersedia dan diketahui potensinya untuk memenuhi keinginan. ${ }^{12}$

Gunawan A. Wardhana sebagaimana yang dikutip oleh A.S. Munandar sepenggal kalimat kutipan dari Harbison menyatakan bahwa sumber daya manusia mencakup semua energi, keterampilan, bakat, dan pengetahuan manusia yang dipergunakan secara potensial dapat atau harus dipergunakan untuk tujuan produksi dan jasa-jasa yang bermanfaat. ${ }^{13}$

Dari beberapa definisi di atas dapat diambil kesimpulan bahwa yang dimaksud dengan sumber daya manusia itu adalah tenaga atau kekuatan/kemampuan yang dimiliki oleh seseorang berupa daya pikir, daya cipta, karsa dan karya yang masih tersimpan dalam dirinya sebagai energi potensial yang siap dikembangkan menjadi daya-daya berguna sesuai dengan keinginan manusia itu sendiri.

\section{Islam tentang Signifikansi Sumber Daya Manusia (SDM) Berkualitas}

Manusia merupakan makhluk yang memiliki kemampuan istimewa dan menempati kedudukan tertinggi di antara makhluk lainnya, yakni menjadi khalifah (wakil) Tuhan di muka bumi (Q.S. al-Baqarah $\{2\}$ : 30)

"Ingatlah ketika Tuhanmu berfirman kepada para malaikat:"Sesungguhnya Aku hendak menjadikan seorang khalifah di mukabumi."

Ayat di atas dipertegas dengan ayat lainnya dalam (Q.S. al-An.am $\{6\}: 165)$.

"Dan Dialah yang menjadikan kamu penguasa-penguasa di bumidan dia meninggikan sebahagian kamu atas sebahagian (yang lain)beberapa derajat, untuk mengujimu tentang apa yang diberikan-Nyakepadamu”.

Islam menghendaki manusia berada pada tatanan yang tinggi dan luhur. Oleh karena itu manusia dikaruniai akal, perasaan, dan tubuh yang sempurna. Islam, melalui ayat-ayat al-Qur'an telah mengisyaratkan tentang kesempurnaan diri manusia, seperti antara lain disebutkan dalam surat at-Tin $\{95\}$ ayat 4 :

"Sesungguhnya Kami telah menciptakan manusia dalam bentuk yangsebaik-baiknya".

${ }^{12}$ Suprihatin Gunaharja, et.al., Pengembangan Sumber Daya Keluarga(Jakarta: BPK Gunung Mulia, 2003), Cet. I, 4.

${ }_{13}$ A.S. Munandar, Pengembangan Sumber Daya Manusia dalam Rangka Pembangunan Nasional(Jakarta: Djaya Pirusa, 2001), 9. 
Kesempurnaan demikian dimaksudkan agar manusia menjadi individu yang dapat mengembangkan diri dan menjadi anggota masyarakat yang berdaya guna sehingga dapat mengembangkan seluruh potensi sumber daya yang dimilikinya. Berbeda dengan Islam, menurut orangorang Barat, manusia adalah termasuk bangsa binatang menyusui (mamalia). Yusuf Qardhawi, ulama kontemporer karismatik asal Mesir mengutip pendapat Ernest Haeckel, pemuka aliran biologisme bangsa Jerman yang mengatakan: tidak ada sangsi lagi bahwa dalam segala hal manusia sungguh-sungguh adalah binatang beruas tulang belakang, yakni binatang yang menyusui. ${ }^{14}$ Pendapat ini tentu saja memanggil kembali memori kita tentang apa yang pernah dilontarkan oleh ilmuan Barat lainnya, yaitu Charles Darwin dalam teori evolusi.-nya bahwa asal-muasal bangsa manusia adalah kera. Tentu teori ini ditolak oleh Islam karena bukan hanya bertentangan dengan risalah Islam namun juga secara tak langsung merendahkan derajat manusia itu sendiri sebagai seorang khalifah di bumi.

Lain halnya dengan Julian Offrey de Lammetrie, seorang materialis berkebangsaan Perancis yang mengatakan bahwa tidak terdapat perbedaan antara manusia dengan binatang dan karena itu manusia adalah suatu mesin. $^{15}$

Definisi yang dikemukakan oleh para ahli filsafat mengenai manusia tidaklah berbeda dengan pendapat di atas. Mereka memberikan sebutan manusia sebagai binatang dengan beberapa sikap menurut kenyataan tindakan manusia dalam kehidupannya, antara lain yaitu:

a. Homo Sapiens, menurut Lonnaeus yaitu binatang yang mempunyai budi (akal) dan ahli agama kristen menyebut manusia sebagai animal rational, yaitu binatang yang berfikir.

b. Homo Laquen, menurut Revesz dalam Das Problem Des Ursprungs end Sprache. manusia ialah binatang yang pandai menciptakan bahasa dan menjelmakan pikiran serta perasaan dalam kata-kata tersusun.

c. Homo Faber, menurut Bergson dalam .L.Evolution Creatrice. Yaitu binatang yang pandai membuat alat perkakas.

d. Zoon Politicon, menurut Aristoteles yaitu binatang yang pandai bekerja sama, bergaul dengan orang lain dan mengorganisasi diri untuk memenuhi kebutuhan hidupnya.

e. Homo Religious, yaitu binatang yang dasarnya beragama. f. Homo Economicus, yaitu binatang yang takluk pada undang-undang ekonomi dan dia bersifat ekonomikus. ${ }^{16}$

${ }^{14}$ Yusuf Qardhawi, Berinteraksi dengan Al-Qur.an(Jakarta: Gema Insani Press, 1999), Cet. I, 256.

${ }^{15}$ Syahminan Zaini dan Ananto Kusuma Seta, Wawasan al-Qur'an tentang Pembangunan Manusia Seutuhnya(Jakarta: Kalam Mulia, 2006), Cet. II, 5.

${ }^{16}$ Syahid Mu.amar Pulungan, Manusia dalam al-Qur'an (Surabaya: Bina Ilmu, 2004), Cet.1, 15-17. 
Tetapi al-Qur.an menegaskan bahwa manusia adalah makhluk yang bertanggung jawab, yang diciptakan dengan sifat-sifat ketuhanan. Definisi ini mengandung tiga unsur yaitu:

a. Manusia adalah ciptaan Allah swt. (Q.S. an-Nahl \{16\}: 4)

"Dia telah menciptakan manusia dari mani, tiba-tiba ia menjadipembantah yang nyata".

b. Manusia adalah makhluk yang bertanggung jawab kepada Allah swt.Menurut al-Qur'an, yang akan dipertanggungjawabkan itu ialah:

a) Tugas manusia sebagai khalifah Allah di muka bumi sebagaimana(Q.S. 2: 30) dan (Q.S. al-An.am \{6\}: 165) tersebut di atas.

b) Semua nikmat Allah yang pernah diterima manusia (Q.S. atTakatsur\{102\}: 8)

"Kemudian kamu pasti akan ditanyai pada hari itu tentangkenikmatan (yang kamu megah-megahkan di dunia itu)”.

c) Semua tingkah laku manusia selama hidup di dunia ini (Q.S. anNahl $\{16\}: 93)$

"Dan Sesungguhnya kamu akan ditanya tentang apa yang telah kamukerjakan”.

d) Semua ide, gagasan, ilmu dan teknologi yang diadakan manusia (Q.S.al-Israa $\{17\}$ : 36)

"Dan janganlah kamu mengikuti apa yang kamu tidak mempunyaipengetahuan tentangnya. Sesungguhnya pendengaran, penglihatandan hati, semuanya itu akan diminta pertanggungan jawabnya".

e) Semua ikrar dan janji yang diadakan manusia (Q.S. al-Israa $\{17\}$ : 34)

"Sesungguhnya janji itu pasti diminta pertanggungan jawabnya".

c. Manusia diciptakan dengan sifat-sifat ketuhanan.

Manusia mempunyai sifat-sifat ketuhanan seperti sifat-sifat yang dipunyaioleh Tuhan. Seperti berkuasa, berkehendak, berilmu, penyayang,pengasih, melihat, mendengar, berkata-kata dan sebagainya. Tetapi sifat-sifat ini tidaklah sama. Tuhan adalah pencipta, sedangkan manusia adalahciptaan-Nya. Pencipta dengan ciptaan-Nya tidak sama. Karena itu sifat-sifatTuhan yang ada pada manusia tentulah sesuai dengankemanusiaannya. ${ }^{17}$

Dengan demikian Islam memandang manusia sangat mulia dengan sumberajarannya yaitu al-Qur'an. Ia telah memotret manusia dalam bentuknya yang utuh danmenyeluruh.

${ }^{17}$ Syahminan Zaini dan Ananto Kusuma Seta. Wawasan al-Qur'an tentang Pembangunan Manusia 7. 


\section{Potensi Dasar Manusia}

Para filosof tidak pernah sependapat tentang potensi apa yang perludikembangkan oleh manusia. Melalui pendekatan historis, Hasan Langgulungmenjelaskan bahwa di Yunani Kuno satu-satunya potensi manusia yang harusdikembangkan di kerajaan Sparta adalah potensi jasmaninya, tetapi sebaliknya dikerajaan Athena yang dipentingkan adalah kecerdasan otaknya. ${ }^{18}$

Beberapa ahli filsafat pendidikan Islam telah mencoba mengklasifikasikanpotensi manusia, diantaranya yaitu menurut KH. A. Azhar Basyir, bila manusiaditinjau dari substansinya, maka manusia terdiri dari potensi materi yang berasal daribumi dan potensi ruh yang berasal dari Tuhan. ${ }^{19}$ Pendapat senada juga dikemukakanoleh Syahminan Zaini yang menyatakan bahwa unsur pembentuk manusia terdiri dari tanah dan potensi rohani dari Allah. ${ }^{20}$ Dalam redaksi lain, Muhaimin dan AbdulMujib berpendapat bahwa pada hakekatnya manusia terdiri dari komponen jasad(jasmani) dan komponen jiwa (rohani), menurut mereka komponen jasmani berasaldari tanah dan komponen rohani ditiupkan oleh Allah. ${ }^{21}$ Demikian pula kesimpulanyang diambil Abuddin Nata berdasarkan pendapat para ahli filsafat pendidikan,bahwa secara umum manusia memiliki dua potensi, yaitu potensi jasmani dan potensirohani. ${ }^{22}$

Dari pendapat yang dikemukakan di atas, ternyata potensi manusia dapatdiklasifikasikan kepada potensi jasmani dan potensi rohani. Berbeda denganklasifikasi yang dikemukakan di atas, beberapa ahli filsafat pendidikan menguraikanpotensi rohani manusia ke dalam beberapa bagian, sebagaimana pendapat BarmawieUmary yang menyatakan bahwa potensi rohani manusia itu terdiri dari empat unsurpokok, yaitu roh, qalb, nafs, dan akal. ${ }^{23}$ Pembagian Barmawie Umary ini sedikitberbeda dengan klasifikasi potensi rohani yang dikemukakan oleh Muhaimin danAbdul Mujib. Menurut keduanya potensi rohani manusia itu dibagi tiga yaitu, potensifitrah, qolb, dan akal. ${ }^{24}$

\section{Sumber Daya Manusia Berkualitas Menurut Islam}

Manusia diciptakan oleh Allah sebagai penerima dan pelaksana ajaran sehingga ia ditempatkan pada kedudukan yang mulia. Untuk mempertahankan kedudukannya yang mulia dan bentuk pribadi yang

18 Hasan Langgulung, Manusia dan Pendidikan; Suatu Analisa Psikologi dan Pendidikan(Jakarta: Pustaka al-Husna, 2005), Cet. III, 261-262.

${ }^{19}$ Muhammad Syamsudin, Manusia dalam Pandangan KH. A. Azhar Basyir (Yogyakarta: Titian Ilahi Press, 2007), Cet. II, 77.

${ }^{20}$ Syahminan Zaini, Penyakit Rohani Pengobatannya (Jakarta: Kalam Mulia, 2006), Cet. III, 6 .

${ }^{21}$ Muhaimin dan Abdul Mujib, Pemikiran Pendidikan Islam; Kajian Filosofis dan Kerangka Dasar Operasionalisasinya (Bandung: Tri Genda Karya, 2003), Cet. I, 10-11.

${ }^{22}$ Abuddin Nata, Filsafat Pendidikan Islam(Jakarta: Logos Wacana Ilmu, 1997), Cet. I, 35.

${ }^{23}$ Barmawie Umary, Materi Akhlak (Solo: Ramadhani, 1989), Cet. I, 21.

${ }^{24}$ Muhaimin dan Mujib, Pemikiran Pendidikan Islam; Kajian Filosofis dan Kerangka Dasar Operasionalisasinya (Bandung: Tri Genda Karya, 2003), Cet. I, 11. 
bagus itu, Allah melengkapinya dengan akal dan perasaan yang memungkinkannya menerima dan mengembangkan ilmu pengetahuan dan membudayakan ilmu yang dimilikinya. Ini berarti bahwa kedudukan manusia sebagai makhluk yang mulia itu karena akal dan perasaan, ilmu pengetahuan dan kebudayaan yang seluruhnya dikaitkan kepada pengabdian pada Pencipta. ${ }^{25}$

Potensi-potensi yang diberikan kepada manusia pada dasarnya merupakan petunjuk (hidayah) Allah yang diperuntukkan bagi manusia supaya ia dapat melakukan sikap hidup yang serasi dengan hakekat penciptaannya. ${ }^{26}$ Sejalan dengan upaya pembinaan seluruh potensi manusia, Muhammad Quthb berpendapat bahwa Islam melakukan pendidikan dengan melakukan pendekatan yang menyeluruh terhadap wujud manusia, sehingga tidak ada yang tertinggal dan terabaikan sedikitpun, baik dari segi jasmani maupun segi rohani, baik kehidupannya secara mental, dan segala kegiatannya di bumi ini. Islam memandang manusia secara totalitas, mendekatinya atas dasar apa yang terdapat dalam dirinya, atas dasar fitrah yang diberikan Allah kepadanya, tidak ada sedikitpun yang diabaikan dan tidak memaksakan apapun selain apa yang dijadikannya sesuai dengan fitrahnya. Pendapat ini memberikan petunjuk dengan jelas bahwa dalam rangka mencapai pendidikan Islam mengupayakan pembinaan seluruh potensi secara serasi dan seimbang. ${ }^{27}$

Hasan Langgulung melihat potensi yang ada pada manusia sangat penting sebagai karunia yang diberikan Allah untuk menjalankan tugasnya sebagai khalifah di muka bumi. Suatu kedudukan yang istimewa di dalam alam semesta ini. Manusia tidak akan mampu menjalankan amanahnya sebagai seorang khalifah, tidak akan mampu mengemban tanggung jawabnya jikalau ia tidak dilengkapi dengan potensipotensi tersebut dan mengembangkannya sebagai sebuah kekuatan dan nilai lebih manusia dibandingkan makhluk lainnya. ${ }^{28}$ Artinya, jika kualitas SDM manusianya berkualitas maka ia dapat mempertanggungjawabkan amanahnya sebagai seorang khalifah dengan baik. Kualitas SDM ini tentu saja tak hanya cukup dengan menguasai ilmu pengetahuan dan teknologi (iptek), tetapi juga pengembangan nilainilai rohani-spiritual, yaitu berupa iman dan taqwa (imtaq). Dari penjabaran di atas dapat dimengerti bahwa pengembangan SDM sangat penting, tak hanya dari sudut ilmu pengetahuan dan teknologi. Namun, tak kalah pentingnya adalah dimensi spiritual dalam pengembangan SDM. Kualitas SDM tidak akan sempurna tanpa ketangguhan mental-spiritual keagamaan.

Sumber daya manusia yang mempunyai dan memegang nilai-nilai agama akan lebih tangguh secara rohaniah. Dengan demikian akan lebih mempunyai tanggung jawab spiritual terhadap ilmu pengetahuan serta

\footnotetext{
${ }^{25}$ Zakiah Daradjat, Ilmu Pendidikan Islam(Jakarta: Bumi Aksara, 1996), Cet. III, 3.

${ }^{26}$ Jalaluddin, Filsafat Pendidikan Islam (Jakarta: Raja Grafindo Persada, 2006), Cet.II, 108.

${ }^{27}$ Abuddin Nata, Filsafat Pendidikan Islam(Jakarta: Logos Wacana Ilmu, 2007), Cet. I,

${ }^{28}$ Hasan Langgulung, Manusia dan Pendidikan....., 57.
} h.51 
teknologi. Sumber daya manusia yang tidak disertai dengan kesetiaan kepada nilai-nilai keagamaan, hanya akan membawa manusia ke arah pengejaran kenikmatan duniawi atau hedonisme belaka. Dan jika semangat hedonisme sudah menguasai manusia, bisa diramalkan yang terjadi adalah eksploitasi alam sebesar-besarnya tanpa rasa tanggung jawab dan bahkan penindasan manusia terhadap manusia lain. ${ }^{29}$ Kesimpulan lengkap yang berkait dengan acuan bagi pengembangan SDM berdasarkan konsep Islam, menjadi .membentuk manusia yang berakhlak mulia, yang senantiasa menyembah Allah yang menebarkan rahmat bagi alam semesta dan bertaqwa kepada Allah. Inilah yang menjadi arah tujuan pengembangan SDM menurut konsep Islam.

\section{Kesimpulan}

Manusia merupakan makhluk yang memiliki kemampuan istimewa di antara makhluk lainnya. Kemampuan demikian dimaksudkan agar manusia menjadi individu yang dapat mengembangkan seluruh potensi sumber daya yang dimilikinya. Secara umum potensi manusia diklasifikasikan kepada potensi jasmani dan potensi rohani. Hasan Langgulung melihat potensi yang ada pada manusia tersebut sangat penting sebagai karunia yang diberikan Allah untuk menjalankan tugasnya sebagai khalifah di muka bumi, inilah tujuan utama atau akhir (ultimate aim) pendidikan Islam.

Potensi-potensi yang diberikan kepada manusia pada dasarnya merupakan petunjuk (hidayah) Allah yang diperuntukkan bagi manusia supaya ia dapat melakukan sikap hidup yang serasi dengan hakekat penciptaannya. Pengembangan SDM berdasarkan konsep Islam, ialah membentuk manusia yang berakhlak mulia, senantiasa menyembah Allah yang menebarkan rahmat bagi alam semesta dan bertaqwa kepada Allah. Inilah yang menjadi arah tujuan pengembangan SDM menurut konsep Islam.

\section{DAFTAR PUSTAKA}

Fadjar, A. Malik. 1999.Madrasah dan Tantangan Modernitas.Bandung: Mizan. 2009. Reorientasi Pendidikan Islam, Jakarta: Fajar Dunia.

Munandar, A.S. 2001. Pengembangan Sumber Daya Manusia dalam Rangka Pembangunan Nasional.Jakarta: Djaya Pirusa.

Assegaf, Abd. Rachman.2004. Membangun Format Pendidikan Islam di Era Globalisasi. dalam Imam Machali dan Musthofa (Ed.), Pendidikan Islam dan Tantangan Globalisasi. Yogyakarta: Ar-Ruzz Media.

Latif, Abdul. 1996. Pengembangan Sumber Daya Manusia yang Berkualitas Menghadapi Era Pasar Bebas. Jakarta: DPP HIPPI.

${ }^{29}$ Wakhudin, Tarmizi Taher; Jembatan Umat, Ulama dan Umara, (Bandung: Granesia, 2008), h. 240-241 
Nata, Abuddin. 2007. Filsafat Pendidikan Islam. Jakarta: Logos Wacana Ilmu.

Suhandana, Anggan. 2007. Pendidikan Nasional Sebagai Instrumen Pengembangan SDM. Bandung: Mizan.

Umary, Barmawie. 1989. Materi AkhlakSolo: Ramadhani.

Zainun, Buchori. 2003. Manajemen Sumber Daya Manusia. Jakarta: Gunung Agung.

Depdikbud, 1999. Kamus Besar Bahasa Indonesia. Jakarta: Balai Pustaka.

Langgulung, Hasan. 2005. Manusia dan Pendidikan; Suatu Analisa Psikologi dan Pendidikan. Jakarta: Pustaka al-Husna.

Jalaluddin. 2006.Filsafat Pendidikan Islam.Jakarta: Raja Grafindo Persada.

Vaizey, John, 1980. Pendidikan di Dunia Modern.Jakarta: Gunung Agung.

Muhaimin dan Abdul Mujib. 2003. Pemikiran Pendidikan Islam; Kajian Filosofis dan Kerangka Dasar Operasionalisasinya.Bandung: Tri Genda Karya.

Syamsudin, Muhammad. 2007.Manusia dalam Pandangan KH. A. Azhar Basyir Yogyakarta: Titian Ilahi Press.

Arifin, Muzayyin. 2003.Ilmu Pendidikan Islam.Jakarta: Bumi Aksara.

Pamungkas, Sri Bintang.2003. Dengan Sumber Daya Manusia (SDM) dan IPTEK Mengatasi Kemiskinan, Mencapai Kemandirian.Jakarta: Seminar dan Sarasehan Teknologi.

Gunaharja, Suprihatin. et.al. 2003. Pengembangan Sumber Daya Keluarga. Jakarta: BPK Gunung Mulia.

Mu'amar Pulungan, Syahid. 2004. Manusia dalam al-Qur'an. Surabaya: Bina Ilmu.

Zaini, Syahminan dan Ananto Kusuma Seta. 2006.Wawasan al-Qur'an tentang Pembangunan Manusia Seutuhnya.Jakarta: Kalam Mulia.

Zaini, Syahminan. 2008. Penyakit Rohani Pengobatannya.Jakarta: Kalam Mulia.

Wakhudin, 2008.Tarmizi Taher; Jembatan Umat, Ulama dan Umara. Bandung: Granesia.

Qardhawi, Yusuf. 1999.Berinteraksi dengan Al-Qur'an.Jakarta: Gema Insani Press.

Suit, Yusuf. 2006.Sikap Mental dalam Manajemen SDM.Jakarta: Ghalia Indonesia.

Daradjat, Zakiah. 1996.Ilmu Pendidikan Islam.Jakarta: Bumi Aksara. 